\title{
PRINSIP DAN NORMA HUKUM PENGADAAN BARANG/JASA SECARA
}

\author{
SWAKELOLA
}

Oleh : Sarah S. Kuahaty

\begin{abstract}
Procurement of goods/services the government is a government activity that has generally been regulated in Presidential Regulation Number 54 Year 2010 Concerning the Procurement of Goods/services of the Government. Procurement conducted by the government can be implemented by using a provider of goods/services or self-managed. In the procurement of goods/services are self-managed, then the planned procurement of work, work, and supervised solely by implementing self-management, among others can be done by the Ministry / Institution / Work Unit Regional / Other Institutions and Community Group. In the implementation of procurement of goods/services should be based on the principle of selfmanaged Efficient, Effective, Transparent, Open, Competitive, Fair / non-discriminatory, and Accountable. In the procurement of goods/services in self-management is also inseparable from the making of the contract, then in addition to these principles are self-managed procurement should also be implemented based on the principles as set forth in Civil Code principle of freedom of contract, Consensualism Principles, Principle of equality of the parties, Principles Pacta sunt servanda, and the Principles of good faith
\end{abstract}

\section{Key word : Government Procurement, self-managed}

\section{A. PENDAHULUAN}

Pelaksanaan pembangunan nasional berupa pembangunan infrastruktur dalam bentuk pembangunan gedung, pembangunan perumahan, pembangunan jalan dan lain sebagaimana ditujukan bagi peningkatan kesejahteraan masyarakat. Untuk mencapai hal ini, pemerintah berupaya meningkatkan pelayanan publik kepada masyarakat yang dilakukan dalam bentuk kebijakan maupun regulasi. Pemerintah, baik pemerintah pusat maupun pemerintah daerah dalam pembangunan infrastruktur untuk menyediakan kebutuhan masyarakat merupakan bagian penting dari penyelenggaraan tugas pemerintahan.
Tindakan pemerintah dalam penyelenggaraan tugas pemerintahan tersebut dilakukan melalui kegiatan pengadaan Barang/jasa pemerintah yang merupakan salah satu aktivitas pemerintah dalam rangka pelayanan publik. Pengadaan Barang/jasa pemerintah di Indonesia saat ini didasarkan pada Peraturan Presiden Nomor 54 Tahun 2010 Tentang Pengadaan Barang/Jasa Pemerintah (selanjutnya disebut Perpres Nomor 54 Tahun 2010). Peraturan Presiden ini dalam pelaksanaannya telah mengalami beberapakali perubahan diantaranya Keputusan Presiden Nomor 80 Tahun 2003, Keputusan Presiden Nomor 61 Tahun 2004, Peraturan Presiden Nomor 32 Tahun 2005, Peraturan Presiden Nomor 70 Tahun 2005, Peraturan Presiden Nomor 8 
Tahun 2006, Peraturan Presiden Nomor 79 Tahun 2006, dan Peraturan Presiden Nomor 85 Tahun 2006.

Berdasarkan Pasal 1 angka 1 Perpres Nomor 54 Tahun 2010, pengadaan barang/jasa pemerintah adalah kegiatan untuk memperoleh barang/jasa oleh Kementerian / Lembaga / Satuan Kerja Perangkat Daerah/Institusi lainnya yang prosesnya dimulai dari perencanaan kebutuhan sampai diselesaikannya seluruh kegiatan untuk memperoleh barang/jasa. Lebih lanjut diatur dalam pasal 3 Perpres Nomor 54 Tahun 2010 ini, bahwa pelaksanaan kegiatan pengadaan barang/jasa pemerintah dilakukan melalui pemilihan penyedian barang/jasa dan dengan cara swakelola.

Penyedia barang/jasa dapat ditentukan melalui prosedur pemilihan penyedia barang/jasa atau dengan penunjukan langsung sesuai dengan metode pemilihan dan penunjukan langsung sebagaimana diatur dalam peraturan ini. Sedangkan pengadaan barang/jasa secara swakelola sebagaimana diatur dalam BAB $\mathrm{V}$ dan dijabarkan lebih lanjut dalam Lampiran VI Perpres Nomor 54 Tahun 2010 adalah Pengadaan barang/jasa dimana pekerjaannya direncanakan, dikerjakan dan/atau diawasi sendiri oleh Kementerian / Lembaga / Satuan Kerja Perangkat Daerah / Institusi lainnya sebagai penanggungjawab anggaran, instansi pemerintah lainnya dan/atau kelompok masyarakat. ${ }^{1}$

Dengan demikian pengadaan Barang/ jasa secara Swakelola dapat dilaksanakan oleh:

a. Kementerian/Lembaga/Satuan Kerja Perangkat Daerah/Institusi lainnya selaku penanggungjawab anggaran (selanjutnya disingkat $\mathrm{K} / \mathrm{L} / \mathrm{D} / \mathrm{I})$

b. instansi pemerintah lain;

c. kelompok masyarakat pelaksana swakelola.

1 Lihat Pasal 1 angka 20 Perpres Nomor 54 Tahun 2010
Dari definisi swakelola di atas, maka definisi tersebut mengandung unsur-unsur pengertian sebagai berikut: ${ }^{2}$

1. Swakelola merupakan salah satu metoda pelaksanaan pekerjaan yang dibutuhkan oleh pemerintah.

2. Pelaksanaan pekerjaan tersebut direncanakan, dikerjakan dan/atau diawasi sendiri oleh pelaksana yang bersangkutan.

Pengadaan Barang/jasa secara swakelola merupakan bentuk pengadaan Barang/jasa pemerintah yang pelaksanaan baik subyek dan obyeknya berbeda, atau tidak dapat dilaksanakan oleh penyedia barang/jasa, namun pelaksanaan pengadaan barang/jasa secara swakelola ini masih menggunakan beberapa prinsip dan norma hukum pengadaan barang/jasa yang dilaksanakan oleh penyedia barang/jasa.

Berdasarkan paparan yang telah dikemukakan di atas, maka yang menjadi permasalahan adalah apa yang menjadi prinsip dan norma hukum dalam pengadaan Barang/jasa secara swakelola?

\section{B. METODE PENULISAN}

Metode yang digunakan dalam penulisan adalah dengan menggunakan tipe penelitian hukum normatif, yakni mengkonsepsikan hukum sebagai norma, kaidah, asas, atau dogma-dogma, dengan menggunakan pendekatan perundangundangan atau Statute Approach ${ }^{3}$ yang dijelaskan secara deskriptif berdasarkan permasalahan dengan berbagai aturan-aturan hukum dan literatur, serta mencari suatu opini hukum tentang masalah yang menjadi objek permasalahan.

2 James Erik Siagian, Pelaksanaan Pekerjaan Swakelola Salah Satu Metode Pengadaan Barang dan Jasa yang Efisien dan Efektif, Forum Infrastruktur Pengadaan Barang dan Jasa, tanggal 3 Agustus 2010, http://www.p2kp.org/forumdetil.asp?mid=23447 \&catid $=22 \&$.

3 Peter Mahmud Marzuki; Penelitian Hukum; Jakarta; Kencana Prenada Media Group; 2005; hal. 96 
Penulisan ini adalah bersifat deskriptif, yaitu menggambarkan serta menguraikan semua bahan hukum yang diperoleh baik bahan hukum primer, bahan Hukum sekunder maupun bahan hukum tersier dari hasil studi kepustakaan yang berkaitan dengan judul penulisan hukum yang secara jelas dan rinci kemudian dianalisis menggunakan teknik kualitatif dimana peneliti mencari, memilih, menghimpun aturan-aturan hukum atau prinsip-prinsip hukum dan data-data yang diperoleh kemudian dianalisis secara deskriptif guna memperoleh jawaban atas permasalahan yang dikemukakan.

\section{HASIL DAN PEMBAHASAN}

Pelaksanaan kegiatan pengadaan Barang/jasa pemerintah dilakukan melalui pemilihan penyedian barang/jasa dan dengan cara swakelola. Penyedia barang/jasa dapat ditentukan melalui prosedur pemilihan penyedia barang/jasa atau dengan penunjukan langsung. Berkaitan dengan hal ini, Yohanes Sogar Simamora ${ }^{4}$ menyatakan bahwa pelaksanaan pengadaan barang dan jasa oleh pemerintah dapat dilakukan dengan dua cara, yaitu: pengadaan yang dilakukan oleh penyedia barang dan jasa dan pengadaan dengan swakelola. Pengadaan pada cara yang pertama dibedakan menjadi dua yakni pengadaan Barang/jasa pemborongan/jasa lainnya dan jasa konsultasi. Tahap ini merupakan tahap yang sangat penting dan menentukan dalam pencapaian tujuan pengadaan. Prinsip dasar pengadaan, yaitu prinsip efisien, efektif, terbuka dan bersaing, transparan, adil/tidak diskriminatif dan akuntabel sebagaimana diatur dalam Pasal 3 Keppres No. 80/2003 hanya bermakna jika prosedur dan tata cara pelaksanaan pengadaan secara konsisten mengacu pada prinsip tersebut.

Pengadaan Barang/jasa dengan swakelola sebagaimana telah dijelaskan

Yohanes Sogar Simamora, Prinsip Hukum Kontrak Dalam Pengadaan Barang dan Jasa Oleh Pemerintah, Disertasi, Universitas Airlangga, Surabaya, 2005, h. 144. sebelumnya dapat dilaksanakan oleh $\mathrm{K} / \mathrm{L} / \mathrm{D} / \mathrm{I}$ selaku penanggungjawab anggaran, dilaksanakan oleh instansi pemerintah lain dan pelaksanaan oleh kelompok masyarakat pelaksana swakelola. Tetapi tidak semua pekerjaan pengadaan Barang/jasa dapat dilaksanakan secara swakelaola. Berdasarkan pasal 26 Perpres 54 Tahun 2010, maka Pekerjaan yang dapat dilakukan dengan Swakelola meliputi:

1. Pekerjaan yang bertujuan untuk meningkatkan kemampuan dan/atau memanfaatkan kemampuan teknis sumber daya manusia serta sesuai dengan tugas pokok K/L/D/I;

2. Pekerjaan yang operasi dan pemeliharaannya memerlukan partisipasi langsung masyarakat setempat;

3. Pekerjaan yang dilihat dari segi besaran, sifat, lokasi atau pembiayaannya tidak diminati oleh Penyedia Barang/jasa;

4. Pekerjaan yang secara rinci/detail tidak dapat dihitung/ditentukan terlebih dahulu, sehingga apabila dilaksanakan oleh Penyedia Barang/jasa akan menimbulkan ketidakpastian dan risiko yang besar;

5. Penyelenggaraan diklat, kursus, penataran, seminar, lokakarya atau penyuluhan;

6. Pekerjaan untuk proyek percontohan (pilot project) dan survei yang bersifat khusus untuk pengembangan teknologi/metode kerja yang belum dapat dilaksanakan oleh Penyedia Barang/jasa;

7. Pekerjaan survei, pemrosesan data, perumusan kebijakan pemerintah, pengujian di laboratorium dan pengembangan sistem tertentu;

8. Pekerjaan yang bersifat rahasia bagi K/L/D/I yang bersangkutan;

9. Pekerjaan Industri Kreatif, inovatif dan budaya dalam negeri;

10. Penelitian dan pengembangan dalam negeri; dan/atau 
11. Pekerjaan pengembangan industri pertahanan, industry alutsista dan industri almatsus dalam negeri.

Pengadaan Swakelola oleh K/L/D/I sebagai penanggung jawab anggaran, oleh instansi pemerintah lain dan oleh kelompok masyarakat direncanakan, dikerjakan dan diawasi sendiri oleh pelaksana swakelola. Walaupun pengadaan dilaksanakan sendiri secara swakelola tetapi bila Unit Layanan Pengadaan (ULP) belum dibentuk, maka harus diawali dengan pembentukan Panitia/Pejabat Pengadaan yang diangkat oleh Pengguna Anggaran atau Kuasa Pengguna Anggaran. ${ }^{5}$ Pengadaan Barag/jasa yang dilaksanakan wajib diumumkan melalui website dan papan pengumuman resmi untuk penerangan umum yang dapat diakses masyarakat umum.

Sebelum pekerjaan dilaksanakan, pelaksana swakelola menyusun daftar kebutuhan, kegiatan, dan membentukan Tim Swakelola dengan ketentuan terdiri dari Tim Perencana, Tim Pelaksana dan Tim Pengawas, yang diangkat oleh Pejabat Pembuat Komitmen sesuai dengan struktur organisasi Swakelola.

Berbeda halnya apabila pelaksana swakelola adalah instansi lain, maka tahap persiapan diawali dengan $\mathrm{K} / \mathrm{L} / \mathrm{D} / \mathrm{I}$ sebagai penggungjawab anggaran menyusun daftar kebutuhan dan kegiatan yang akan dilaksanakan dengan cara Swakelola, kemudian Pengguna Anggaran atau Kuasa Pengguna Anggaran menawarkan secara tertulis kegiatan Swakelola kepada instansi pemerintah lain yang diyakini mampu melaksanakan pekerjaan pengadaan dengan melampirkan KAK, jadwal pelaksanaan dan

\footnotetext{
Pengguna Anggaran sebagaimana yang dimaksud dalam Pasal 1 angka 12 Undang-Undang Nomor 1 Tahun 2004 tentang Perbendaharaan Negara adalah pejabat pemegang kewenangan penggunaan anggaran kementerian negara/lembaga/satuan kerja perangkat daerah. Sedangkan yang dimaksudkan dengan Kuasa Pengguna Anggaran adalah pejabat yang ditunjuk oleh Pengguna Anggaran untuk menggunakan anggaran Kementerian / Lembaga / Satuan Kerja Perangkat Daerah
}

rincian anggaran biaya. Instansi pemerintah lain tersebut mempelajari KAK, jadwal pelaksanaan dan rincian anggaran biaya, apabila instansi lain bukan penanggungjawab anggaran tersebut menyanggupi untuk melaksanakan pekerjaan pengadaan, maka instansi tersebut mengajukan surat kesanggupan kepada Pengguna Anggaran atau Kuasa Pengguna Anggaran. Apabila Pengguna Anggaran atau Kuasa Pengguna Anggaran dan pihak instansi pemerintah lain tersebut sepakat, dapat dibuat naskah kerjasama atau Nota Kesepahaman mengenai pelaksanaan pekerjaan Swakelola. selanjutnya Pejabat Pembuat Komitmen mengadakan Kontrak dengan Pelaksana Swakelola pada Instansi Pemerintah lain Pelaksana Swakelola, berdasarkan Nota Kesepahaman.

Apabila pelaksanaan pekerjaan pengadaan itu dilaksanakan oleh kelompok masyarakat, maka K/L/D/I menyusun kegiatan dan sasaran yang akan dilaksanakan dengan cara Swakelola, berdasarkan hasil evaluasi atas usulan dari Kelompok Masyarakat. Pengadaan barang/jasa hanya diberikan kepada Kelompok Masyarakat yang mampu melaksanakan pekerjaan secara teknis. Pengguna Anggaran atau Kuasa Pengguna Anggaran bertanggungjawab terhadap penetapan Kelompok Masyarakat, termasuk sasaran, tujuan dan besaran anggaran Swakelola. Berdasarkan Pasal 31 huruf (a) Perpres No. 54 Tahun 2010, maka selanjutnya Pejabat Pembuat Komitmen membuat Kontrak pelaksanaan pengadaan Swakelola dengan penanggungjawab Kelompok Masyarakat.

Setelah penandatanganan kontrak Pengadaan, ${ }^{6}$ maka tim perencana dapat memulai pekerjaannya. Khusus untuk pelaksana swakelola oleh instansi lain, maka keanggotaan tim perecana terdiri dari

\footnotetext{
6 Berdasarkan Pasal 1 angka 22, maka yang dimaksudkan dengan Kontrak Pengadaan barang/jasa adalah perjanjian tertulis antara Pejabat Pembuat Komitmen dengan Penyedia Barang/Jasa atau pelaksana Swakelola.
} 
instansi penanggungjawab anggaran dan instansi lain pelaksana pekerjaan pengadaan. $^{7}$ Tim Perencana bertugas menyusun Kerangka Acuan Kerja yang memuat uraian kegiatan yang akan dilaksanakan meliputi latar belakang, maksud dan tujuan, sasaran serta sumber pendanaan, waktu pelaksanaan pekerjaan yang diperlukan, keperluan bahan atau jasa lainnya, peralatan/suku cadang dan/atau tenaga ahli perseorangan secara rinci yang dijabarkan dalam rencana kerja bulanan, rencana kerja mingguan dan rencana kerja harian, rincian biaya pekerjaan yang dijabarkan dalam rencana biaya bulanan dan biaya mingguan, produk yang dihasilkan dan gambar rencana kerja dan spesifikasi teknis (apabila diperlukan). Penyusunan jadwal rencana pengadaan dilaksanakan dengan memperhatikan batas akhir tahun anggaran/batas akhir efektifnya anggaran. Untuk swakelola tertentu dapat dilaksanakan melebihi 1 (satu) tahun anggaran.

Rincian Biaya Pekerjaan yang dibutuhkan untuk membiayai pekerjaan tidak melampaui pagu anggaran yang telah ditetapkan dalam dokumen anggaran dan dituangkan dalam Rencana Anggaran Biaya (RAB). Sedangkan Gambar Rencana Kerja yang dibuat oleh Tim swakelola memuat lay-out, denah, potongan memanjang dan potongan melintang, sedangkan Spesifikasi Teknis disusun mengikuti pedoman/standar yang sesuai dengan yang diperlukan untuk pelaksanaan pekerjaan.

Dalam hal diperlukan bahan, jasa lainnya, peralatan/suku cadang dan/atau tenaga ahli perseorangan, dapat dilakukan kontrak/sewa tersendiri. ${ }^{8}$ Sebelum dilakukan kontrak, proses pengadaannya dilaksanakan sesuai dengan yang ditentukan dalam Dokumen Pengadaan. Jumlah tenaga ahli perseorangan tidak boleh melebihi $50 \%$ (lima puluh persen) dari jumlah keseluruhan

\footnotetext{
7 Lihat Lampiran VI Swakelola Oleh Instansi Pemerintah Lain angka (1) huruf (g)

8 Lihat pasal 28 ayat (2) dan pasal 31 butir (e) Perpres 54 Tahun 2010
}

pegawai K/L/D/I yang terlibat dalam kegiatan Swakelola.

Tim Pelaksana Swakelola melaksanakan pekerjaan yang telah disusun perencanaannya, yaitu melakukan kaji ulang dan pengukuran pada lokasi pekerjaan berdasarkan gambar rencana kerja, mengkaji ulang jadwal pelaksanaan kerja (s-curve) serta jadwal kebutuhan bahan, jasa lainnya, peralatan/suku cadang dan/atau tenaga ahli perseorangan dan mengajukan kebutuhan tersebut kepada Pejabat Pembuat Komitmen untuk diproses oleh Unit Layanan Pengadaan atau Pejabat Pengadaan, mendatangkan dan mengatur tenaga kerja/tenaga ahli perseorangan untuk melaksanakan kegiatan/pekerjaan sesuai dengan jadwal pelaksanaan. selain itu Tim Pelaksana juga bertugas menyusun laporan tentang penerimaan dan penggunaan bahan, jasa lainnya, peralatan atau suku cadang dan/atau tenaga ahli perseorangan.

Tim pelaksana swakelola juga bertugas menyusun laporan kemajuan pekerjaan (realisasi fisik dan keuangan), dan dilaporkan kepada Pejabat Pembuat komitmen secara berkala. laporan tersebut juga oleh Pejabat Pembuat Komitmen kemudian dilaporkan kepada Pengguna Anggaran dan Kuasa Pengguna Anggaran setiap bulan. Pelaporan realisasi pekerjaan dibuat oleh Tim Pelaksana dan dilaporkan kepada PPK yang berisi antara lain :

1. struktur organisasi pekerjaan Swakelola yang terdiri dari pembagian tugas, pendelegasian wewenang dan tanggung jawab serta pengkoordinasian pelaksanaan pekerjaan;

2. persiapan pekerjaan Swakelola yang meliputi kesesuaian gambar pelaksanaan dengan gambar rencana kerja serta kebutuhan bahan, Jasa Lainnya, peralatan/suku cadang dan/atau tenaga ahli perseorangan;

3. pelaksanaan pekerjaan Swakelola yang meliputi kesesuaian jadwal pelaksanaan pekerjaan terhadap jadwal rencana pelaksanaan pekerjaan, penyerapan keuangan, penyerahan pekerjaan sampai 
dengan selesai $100 \%$ (sasaran akhir pekerjaan telah tercapai) dan foto-foto dokumentasi; dan

4. penggunaan bahan, Jasa Lainnya, peralatan/suku cadang dan/atau tenaga ahli perseorangan.

Setelah pelaksanaan pekerjaan Swakelola selesai $100 \%$ (sasaran akhir pekerjaan telah tercapai), Ketua Tim Pelaksana menyerahkan pekerjaan kepada PPK, dan kemudian PPK menyerahkan pekerjaan dan laporan pekerjaan selesai kepada Pengguna Anggaran atau Kuasa Pengguna Anggaran melalui Berita Acara Serah Terima Hasil Pekerjaan. Setelah dilakukan penyerahan pekerjaan, dilanjutkan dengan proses penyerahan aset sesuai dengan peraturan perundang-undangan.

Pengawasan pekerjaan Swakelola dilakukan oleh Tim Pengawas yang di bentuk oleh Pejabat pembuat komitmen, sedangkan untuk pelaksana swakelola oleh kelompok masyarakat, maka tim pelaksana berasal dari kelompok masyarakat. Tugas utama dari Tim Pengawas adalah untuk mengawasi pekerjaan mulai dari persiapan sampai akhir pelaksanaan pekerjaan Swakelola meliputi pengawasan administrasi yang dilakukan terhadap dokumentasi pelaksanaan kegiatan dan pelaporan, pengawasan teknis terhadap hasil pelaksanaan pekerjaan dan pengawasan Keuangan. Apabila dari hasil pengawasan ditemukan penyimpangan, Pejabat Pembuat Komitmen atau pun kelompok masyarakat harus segera mengambil tindakan. ${ }^{9}$

Tim Pengawas melakukan evaluasi setiap minggu terhadap pelaksanaan pekerjaan yang meliputi pengadaan dan penggunaan bahan, pengadaan dan penggunaan tenaga kerja/ahli, pengadaan dan penggunaan peralatan/suku cadang, realisasi keuangan dan biaya yang diperlukan, pelaksanaan fisik dan/atau hasil kerja setiap jenis pekerjaan. Dari hasil evaluasi tersebut, Tim Pengawas memberikan masukan dan rekomendasi

9 Lihat Pasal 29 huruf (J) Perpres Nomor 54 Tahun 2010 untuk memperbaiki dan meningkatkan pelaksanaan pekerjaan Swakelola selanjutnya.

Dengan demikian, bagi pengadaan barang/jasa dengan swakelola, maka bagi Pejabat Pembuat Komitmen maupun pelaksana swakelola berlaku prinsip-prinsip dan norma-norma hukum sebagaimana diatur dalam Perpres 54 Tahun 2010 terutama yang diberlakukan bagi pengadaan Barang/jasa dengan penyedia Barang/jasa, maka dalam pengadaan Barang/jasa dengan swakelola pun harus memiliki landasan prinsip-prinsip dan norma hukum yang berlaku, meliputi: ${ }^{10}$

1. Efisien, berarti Pengadaan Barang/jasa harus diusahakan dengan menggunakan dana dan daya yang minimum untuk mencapai kualitas dan sasaran dalam waktu yang ditetapkan atau menggunakan dana yang telah ditetapkan untuk mencapai hasil dan sasaran dengan kualitas yang maksimum.

2. Efektif, berarti Pengadaan Barang/jasa harus sesuai dengan kebutuhan dan sasaran yang telah ditetapkan serta memberikan manfaat yang sebesarbesarnya.

3. Transparan, berarti semua ketentuan dan informasi mengenai Pengadaan Barang/jasa bersifat jelas dan dapat diketahui secara luas oleh Penyedia Barang/jasa yang berminat serta oleh masyarakat pada umumnya.

4. Terbuka, berarti Pengadaan Barang/jasa dapat diikuti oleh semua Penyedia Barang/jasa yang memenuhi persyaratan/kriteria tertentu berdasarkan ketentuan dan prosedur yang jelas.

5. Bersaing, berarti Pengadaan Barang/jasa harus dilakukan melalui persaingan yang sehat diantara sebanyak mungkin Penyedia Barang/jasa yang setara dan memenuhi persyaratan, sehingga dapat diperoleh Barang/jasa yang ditawarkan secara kompetitif dan tidak ada intervensi

10 Lihat Penjelasan Pasal 5 Perpres Nomor 54 Tahun 2010 Tentang Pengadaan Barang/jasa Pemerintah 
yang mengganggu terciptanya mekanisme pasar dalam Pengadaan Barang/jasa.

6. Adil/tidak diskriminatif, berarti memberikan perlakuan yang sama bagi semua calon Penyedia Barang/jasa dan tidak mengarah untuk memberi keuntungan kepada pihak tertentu, dengan tetap memperhatikan kepentingan nasional.

7. Akuntabel, berarti harus sesuai dengan aturan dan ketentuan yang terkait dengan Pengadaan Barang/jasa sehingga dapat dipertanggungjawabkan.

Pengadaan dengan swakelola juga melibatkan kontrak didalamnya, baik itu kontrak antara Pejabat Pembuat Komitmen dan pelaksana swakelola baik instansi lain dan kelompok masyarakat, maupun kontrak antara Pejabat Pembuat Komitmen dengan penyedia Barang/jasa maupun tenaga ahli, maka berkaitan dengan adanya hubungan kontraktual ini, Selain prinsip-prinsip sebagaimana diatur dalam Perpres Nomor 54 Tahun 2010, pengadaan barang/jasa secara swakelola juga berlaku prinsip-prinsip hukum kontrak, yang bersumber dari Hukum Perikatan sebagimana diatur dalam Buku III Kitab Undang-Undang Hukum Perdata (KUH Perdata). Pasal 1338 KUH Perdata menyebutkan bahwa:

"Semua perjanjian yang dibuat secara sah berlaku sebagi undang-undang bagi mereka yang membuatnya. Suatu perjanjian tidak dapat ditarik kembali selain dengan sepakat kedua belah pihak atau karena alasanalasan yang karena undang-undang dinyatakan cukup untuk itu. Suatu perjanjian harus dilaksanakan dengan itikad baik"

Dari rumusan ketentuan Pasal 1338 KUH Perdata di atas, maka terdapat 6 (enam) prinsip hukum kontrak yang terkandung di dalamnya yakni:

a. Kebebasan berkontrak (Partij autonomie) yang dapat dilihat dari penjabaran kalimat "semua perjanjian" yang memberikan makna bahwa para pihak bebas untuk memperjanjikan apa saja yang mereka inginkan. Tetapi kebebasan yang diberikan dengan syarat tidak bertentangan dengan dengan undang-undang, ketertiban umum dan kesusilaan; ${ }^{11}$

b. Konsensualisme, dapat dilihat dari perumusan kalimat "dibuat secara sah" hal ini berarti bahwa, setiap perjanjian yang dilakukan haruslah mengandung unsur-unsur sahnya suatu perjanjian. Unsur-unsur sahnya suatu perjanjian ${ }^{12}$ yakni kesepakatan mereka yang mengikatkan dirinya, kecakapan untuk membuat suatu perikatan, suatu hal tertentu, suatu sebab yang diperbolehkan. Syarat pertama dan kedua disebut syarat subjektif, karena menyangkut subjek pembuat kontrak, sedangkan syarat yang ketiga dan keempat adalah syarat objektif karena menyangkut objek dari kontrak.

c. Pacta sunt Servanda, dapat disimpulkan dari perumusan kalimat "sebagai undang-undang" hal ini berarti setiap perjanjian yang dilakukan oleh para pihak harus dipatuhi dan dihormati oleh para pihak yang membuatnya karena perjanjian tersebut merupakan undangundang bagi mereka yang membuatnya.

d. Privity of Contract, prinsip ini dapat dilihat dari perumusan kalimat "mereka yang membuatnya" hal ini memberikan makna bahwa suatu perjanjian hanya berlaku bagi para pihak yang membuatnya.

e. Kesederajatan para pihak, prinsip ini dapat disimpulkan dari kalimat "sepakat kedua belah pihak" sebagaimana yang telah disinggung sebelumnya bahwa kesepakatan adalah merupakan salah

11 Pasal $1337 \mathrm{BW}$

12 H. Salim, HS, et. al, Perancangan Kontrak dan Memorandum of Understanding (MoU), Sinar Grafika, Jakarta, 2007, h. 9; H. Salim HS, Hukum Kontrak Teori dan Teknik Penyusunan Kontrak, Sinar Grafika, Jakarta, 2006, h.33; H.R. Daeng Naja, Contract Drafting, Citra Aditya Bakti, Bandung, 2006, h.16, Libertus Jehani, Pedoman Praktis Menyusun Surat Perjanjian, Visi Media, Jakarta Selatan, 2007, h.10. 
satu syarat sahnya suatu perjanjian sehingga dengan adanya kesepakatan, maka memberikan kedudukan yang sama kepada kedua belah pihak, tanpa ada yang lebih diutamakan.

f. Itikad baik (in good faith), prinsip ini jelas terlihat dari perumusan kalimat " harus dilaksanakan dengan itikad baik" makna prinsip itikad baik ini dapat dibagi dua yakni itikad baik subjektif yakni menyangkut kejujuran dan niat baik dari para pihak. Itikad baik objektif yakni bahwa pelaksanaan perjanjian itu harus berjalan di atas rel yang benar dan harus mengindahkan norma-norma, kepatutan dan kesusilaan.

Dengan demikian pelaksanaan pengadaan barang/jasa secara swakelola juga harus didasarkan pada prinsip-prinsip dan norma hukum sebagaimana diatur dalam Buku III KUH Perdata

\section{PENUTUP}

Pengadaan barang/jasa pemerintah merupakan salah satu aktivitas pemerintah yang secara umum telah diatur dalam Perpres Nomor 54 Tahun 2010. Pengadaan Barang/jasa dapat dilakukan menggunakan penyedia Barang/jasa dan dengan secara swakelola. Dalam pengadaan Barang/jasa dengan swakelola, maka pekerjaan yang direncanakan, dikerjakan, dan diawasi sendiri oleh pelaksana swakelola, diantaranya dapat dilakukan oleh $\mathrm{K} / \mathrm{LD} / \mathrm{I}$, instansi pemerintah lainnya dan/atau kelompok masyarakat.

Perencanaan kegiatan pengadaan Barang/jasa dengan swakelola dilaksanakan oleh Kementerian / Lembaga / Satuan Kerja Perangkat Daerah / Institusi lainnya sebagai penanggungjawab anggaran, sedangkan instansi pemerintah lain dan kelompok masyarakat bertindak sebagai pelaksana pekerjaan. Khusus bagi kelompok masyarakat, perencanaan juga merupakan bagian dari pekerjaan sebagai pelaksana kegiatan, tetapi tetap berpedoman pada sasaran yang ingin dicapai dalam pekerjaan pengadaan Barang/jasa dengan swakelola. Dalam pelaksanaan pekerjaan dengan swakelola, Pejabat Pembuat Komitmen dan instansi pemerintah lain dan kelompok masyarakat terikat juga dalam kontrak, yang pelaksanaannya harus didasarkan pada prinsip-prinsip sebagiamana diatur dalam Perpres nomor 54 Tahun 2010 dan Buku III BW.

\section{DAFTAR BACAAN}

\section{A. Buku}

Adrian Sutedi, Aspek Hukum Pengadaan Barang dan Jasa dan Berbagai Permasalahannya, Sinar Grafika, Jakarta, 2008.

Daeng Naja H. R, Contract Drafting, Citra Aditya Bhakti, Bandung, 2006

Salim H. S. et all, Hukum Kontrak Teori dan Teknik Penyusunan Kontrak, Sinar Grafika, Jakarta, 2006

Salim H. S, Perkembangan Hukum Kontrak di luar KUH Perdata, RajaGrafindi Persada, Jakarta, 2006

Simamora, Yohanes Sogar, Hukum Perjanjian - Prinsip Hukum Kontrak Dalam Pengadaan Barang dan Jasa Oleh Pemerintah, LaksBang PRESSindo, Yogyakarta, 2009

\section{B. Peraturan Perundang-Undangan}

Burgerlijk Wetboek (BW,) Staatsblad 1847 Nomor 23

Peraturan Presiden Nomor 54 Tahun 2010

Tentang Pengadaan Barang/jasa

Pemerintah

C. Jurnal, Majalah, Makalah dan Penelitian Ilmiah Lainnya 
Hadjon Philipus M, Tentang Wewenang, YURIDIKA, No. 5 Tahun XII, Sepetember - Desember 1997, Fakultas Hukum Universitas Airlangga, Surabaya, 1997.

Simamora, Yohanes Sogar, Prinsip Hukum Kontrak Dalam Pengadaan Barang dan Jasa Oleh Pemerintah, Disertasi, Universitas Airlangga, Surabaya, 2005

Pembentukan

Dan Pelaksanaan Kontrak Pengadaan, Seminar Nasional Kontrak Pengadaan Barang dan Jasa Oleh Pemerintah, Fakultas Hukum Universitas Airlangga, 2006.

Outlining dan

Bahasa Dalam Perancangan Kontrak, Pelatihan Contract Drafting Teknik Perancangan Kontrak Konstruksi, Laboratorium Pendidikan Hukum Klinik - Fakultas Hukum Universitas Airlangga, 2008.

\section{Webside}

Siagian, James Erik, Pelaksanaan Pekerjaan Swakelola Salah Satu Metode Pengadaan Barang dan Jasa yang Efisien dan Efektif, Forum Infrastruktur Pengadaan Barang dan Jasa, http://www.p2kp.org/ 